BIRNA ARnBJÖRnSDÓtTir, Jón ÓlafsSON OG

ODDNÝ SVERRISDÓTTIR

HÁSKÓLA ÍsLANDS

\title{
Viðhorf háskólastúdenta til tungumálakunnáttu
}

\section{Inngangur}

, 1 ie Grenzen meiner Sprache bedeuten die Grenzen meiner
Welt" (takmörk tungumáls míns eru takmörk heims míns) eru fleyg orð heimspekingsins Ludwigs Wittgenstein sem uppi var á fyrri hluta síðustu aldar. Pessi orð heimspekingsins austurríska lýsa glögglega peirri skoðun að spurningar um heiminn og gerð hans séu pegar öllu er á botninn hvolft spurningar um tungumálið og að skilningur okkar á heiminum ráðist af tungumáli pví sem við höfum á valdi okkar. Tungumálakunnátta stækkar heiminn og eykur fjölbreytileika hans: Pví fleiri tungumál sem hver einstaklingur pekkir eða talar peim mun áhugasamari og forvitnari verður hann um menningu og pjóðlíf annarra málsvæða og fær víðari sýn á menn og málefni. Í frægri tilvitnun í pýska rithöfundinn Johann Wolfgang von Goethe „Wer fremde Sprachen nicht kennt, weiß nichts von seiner eigenen“ (Goethe, J.W.) [sá sem ekki pekkir erlend tungumál veit ekkert um sitt eigið tungumálł er bent á að kunnátta í erlendum tungumálum eykur pekkingu manns á eigin móðurmáli. Tungumálakunnátta breytir einnig samskiptum eins og peir pekkja sem geta átt samskipti utan heimalandsins á máli innfæddra. Pað lýsir áhuga viðkomandi á landi og pjóð og sýnir að sá hinn sami hefur lagt á sig að læra tungumálið, kynnast menningunni og öðlast pannig innsýn í menningarheim viðkomandi 
málsvæðis. Íslenski málshátturinn „heimskt er heimaalið barn“ sýnir að Íslendingar hafa frá aldaöðli gert sér grein fyrir bví hversu mikilvæg samskipti við aðra eru. Pótt upphaflega vísi málshátturinn til pess að börn voru send í fóstur og ólust ekki upp í foreldrahúsum, pá er hann nú notaður í peirri merkingu að fara til annarra svæða og kynnast nýjum menningarheimum. Orðatiltækið „að hleypa heimdraganum “ vísar einnig til pess proska sem fylgir pví að fara að heiman. Íslendingar hafa í gegnum tíðina átt mikil samskipti við aðrar pjóðir í verslun og viðskiptum, menntun, menningu og vísindum og vita hve miklu máli pekking á öđrum tungumálum getur skipt ef menn ætla að ná árangri á pessum sviðum.

Í íslenska menntakerfinu hefur verið lagður metnaður í kennslu erlendra tungumála. Í grunnskólum landsins eru pegar kennd tvö erlend tungumál, enska og danska eða annað Norðurlandamál. Við lok grunnskólans er gert ráo fyrir að nemendur hafi náð hæfni sem metin er sem 3. stig í ensku, dönsku eða öðru Norðurlandamáli. Í aðalnámskrá eru hæfniviðmið skilgreindur heildartími í ensku, dönsku eða öðru Norðurlandamáli og er hæfniviðmiðum í hverju tungumáli skipt í prjú stig með jafna tímaskiptingu að baki (Hæfniviðmið).

Hæfniviðmið við lok gunnskóla eru mjög metnaðarfull og eru sett fyrir hlustun, lesskilning, samskipti, frásögn, ritun, menningarlæsi og námshæfni. Hæfniviðmiðin taka mið af Evrópska tungumálarammanum sem er samevrópskur matsrammi fyrir tungumál og er ætlaður til að skilgreina færni nemenda í tungumálinu. Rammanum er skipt upp í 6 stig eða prep frá A1 til C2. A1 merkir að málnotandinn býr yfir lágmarkskunnáttu í hlustun, lestri samræðum, talmáli og ritun (e. basic user) en C2 stendur fyrir mikla færni málnotandans í fyrrgreindum færnipáttum (e. proficient user) (Europass). Við lok grunnskóla á hæfni nemenda í ensku og dönsku að samsvara stigi B1ef tekið er mið af Evrópska tungumálarammanum, sem merkir að um sjálfstæðan tungumálanotanda er að ræða.

Stytting námstíma til stúdentsprófs úr fjórum árum í prjú hefur nú tekið gildi og pó að áhrif styttingar sé misjöfn eftir pví hvort um er að ræða bekkjakerfi eða áfangakerfi er afleiðinga styttingar farið að gæta á ýmsum sviðum. Um kennslu í erlendum tungumálum er 
fjallað í skólanámskrám framhaldsskóla landsins og er framboð á kennslu mismunandi eftir áherslum einstakra skóla. Við lok framhaldsskóla ættu nemendur pó að vera á stigi B2 eða C1 í ensku og dönsku, par sem byggt er á pekkingu nemenda úr grunnskólunum. Sama verður ekki sagt um kunnáttu nemenda í priðja tungumáli, p.e. frönsku, spænsku og býsku. Í kjölfar styttingar hefur ekki farið dult að tungumál og tungumálanám á undir högg að sækja. Framhaldsskólarnir hafa í vaxandi mæli lagt niður tungumálabrautir og dregið úr framboði á kennslu á erlendum málum. Við styttingu námstíma til stúdentsprófs var áföngum í kennslu í priðja tungumálinu fækkað og í sumum framhaldsskólum hefja nemendur nám í priðja tungumáli seinna en áđur, p.e. á annarri eða priðju önn. Við lok framhaldsskóla eru nemendur almennt pví á stigi sem samsvarar A2 til B1 í frönsku, spænsku og býsku. Petta er mikil breyting á örfáum árum. Fyrir styttingu náms til stúdentsprófs var nemendum boðið upp á sex til sjö áfanga að jafnaði í priðja máli og bjuggu peir pví yfir færni sem samsvaraði B2 í Evrópska tungumálarammanum. Við stúdentspróf höfou nemendur pví staðgóða pekkingu á premur erlendum tungumálum. Sérfræðingar innan Stofnunar Vigdísar Finnbogadóttur í erlendum tungumálum hafa á liðnum tveimur áratugum varað við styttingu framhaldsskólans og pví að fækka einingum í priðja tungumáli til stúdentsprófs. Nægir par að benda á málping sem haldið var á vegum stofnunarinnar, blaðagreinar og skýrslu um styttingu framhaldsskólans frá árinu 2006 sem send var öllum pingmönnum. ${ }^{1}$ Pað skýtur vægast sagt skökku við að draga saman seglin í tungumálakennslu í landi par sem alpjóðavæðing er ráðandi á flestum sviðum og atvinnu- og námstækifæri eru mikil utan landsteinanna. Ungt fólk elst nú upp við pað að skipta oft um starfsvettvang og getur haslað sér völl út um allan heim. Pá eru mikil tækifæri í ferðapjónustu á Íslandi. Einnig er notkun ensku að aukast innan íslenskra fyrirtækja (Birna Arnbjörnsdóttir og Hafdís Ingvarsdóttir, 2018). Í raun ætti pörf

1 „Lærum allar tungur en gleymum ekki okkar eigin“, málbing haldið á vegum Stofnunar Vigdísar Finnbogadóttur í erlendum tungumálum við Háskóla Íslands og Tungumálaáherslu Háskólans í Reykjavík pann 25. janúar 2006 og skýrsluna Tungumál eru lykill ał beiminum. Kennsla erlendra mála î ljósi draga að nýjum námskrám fyrir grunn- og framhaldsskóla sem sömu aðilar gáfu út. Ennfremur birtist grein Auðar Hauksdóttur „Áhyggjur af tungumálamenntun“ í Morgunblađinu pann 23. janúar 2006. 
fyrir kunnáttu í erlendum tungumálum að vera meiri nú á Íslandi en áđur og ásókn í tungumálanám að aukast par sem nemendur læra tungumálið, kynnast menningu málsvæðanna og ná tökum á pvermenningarlegum samskiptum samfara pví að leggja stund á annað nám. Pað er ekki aðeins að á öllum sviðum pjóðlífsins sé pörf á haldgóðri tungumálakunnáttu. Hún eykur einnig faglega hæfni í námsgreinum og gildir bví um allt nám á háskólastigi.

Mála- og menningardeild er eina deild sinnar tegundar á Íslandi og allir nemendur við Háskóla Íslands geta stundað par nám. Unnt er að taka einstök námskeið, hafa tungumál sem aukagrein eða taka eins árs diplómu meðfram öđru námi. Pá er boðið upp á sjálfstýrt tungumálanám í Tungumálamiðstöð Háskóla Íslands, par sem námið er sniðið að pörfum hvers nemanda. Deildin býður upp á kennslu í dönsku, ensku, frönskum fræðum, grísku, latínu, spænsku, sænsku, japönskum fræðum, kínverskum fræðum, ítölsku, rússnesku, MiðAusturlandafræðum og pýsku. Pá hefur Tungumálamiðstöðin einnig um nokkurt skeið boðið upp á nám í pólsku og nú, frá og með pessu ári, einnig hindí. Framboðið er pví afar fjölbreytt og nemendur sem áhuga hafa geta nýtt sér námsframboð deildarinnar eftir pví sem hverjum hentar.

Pó er pröskuldur sem hefur lengi dregið úr möguleikum deilda skólans á pví að leyfa nemendum sínum að taka námskeið utan heimadeildar eða námsgreinar. Orsökina má sennilega rekja til líkansins sem notað er til að deila út fé til sviða skólans. Líkanið byggir fjárúthlutun á svokölluðum preyttum einingum, p.e. á námskeiðum sem nemendur ljúka í námi sínu. Einingarnar sem pannig er lokið fara að mestu leyti til peirra deilda sem bjóða upp á námskeiðin. Hafi nemandi í stjórnamálafræði til dæmis áhuga á pví að bæta við sig námskeiðum í pýsku, nýtur Mála- og menningardeild góðs af pví en Stjórnmálafræðideild tapar. Pannig er deildum í raun refsað fjárhagslega ef pær bjóða nemendum upp á pann möguleika að taka tungumál sem hluta af námi sínu. Рað dregur að sjálfsögðu úr áhuga peirra á að nýta sér fjölbreytt námsframboð Háskólans, sama pótt pað kunni að bæta faglega stöðu nemendanna í samræmi við áhugasvið peirra og framtíðaráætlanir.

Staðan er pví sú að ein meginástæða pess að deildir viðurkenna alla jafna ekki námskeið í erlendum tungumálum eða námskeið sem 
kennd eru í öðrum deildum sem hluta af námi nemenda peirra er að öllum líkindum fjárhagsleg. Par með má einnig færa rök fyrir pví að fjárhagslíkan skólans dragi úr akademískum styrk hans. Kerfið verður e.t.v. til pess að deildir leggja sig síður fram um að miða námskeiðsval við einstaklingsparfir.

Enginn vafi leikur á pví að málakunnátta er mikilvæg í námi og starfi (Birna Arnbjörnsdóttir og Hafdís Ingvarsdóttir, 2018). Mörg peirra starfa sem henta fólki sem hefur nýlokið háskólanámi krefjast tungumálakunnáttu. Sennilega má segja pað sama um flest störf. Sömuleiðis gerir tungumálakunnátta framhaldsnám bæði auðveldara og aðgengilegra á mörgum sviðum. Fyrir pá sem halda áfram rannsóknarnámi hefur tungumálakunnátta oft mikil áhrif á rannsóknargetu - og svo má áfram telja. Pað er pví miður að fjárhagslíkan og skortur á samstarfi hamli pví að nemendur geti nýtt sér pað framboð sem Mála- og menningardeild býður upp á. Minnkandi skilningur á mikilvægi tungumála og dvínandi áhugi á tungumálanámi sem af honum leiðir er Mála- og menningardeild Háskóla Íslands mikið áhyggjuefni. Sú skoðun virðist útbreidd að ekki purfi að kunna önnur tungumál en ensku og pví sé óparfi að leggja sig eftir öðrum málum, hvort sem um er að ræða tungumál nágrannabjóða eða fjarlægari pjóða. Án pess að gera lítið úr mikilvægi enskunnar hefur deildin pví sett sér pað markmið að auka skilning nemenda á kostum pess að bæta við sig tungumálanámi, par á meðal í akademískri ensku en rannsóknir Birnu Arnbjörnsdóttur og Hafdísar Ingvarsdóttur (2018) sýna að kunnátta Íslendinga í ensku er ofmetin.

Fyrsta skrefið til að ná pessu markmiði er að kanna viðhorf nemenda við Háskóla Íslands til tungumálanáms almennt. Í pví skyni ákvað deildin að láta gera könnun meðal allra háskólastúdenta til að komast að pví hver pörf peirra fyrir tungumálakunnáttu væri að eigin mati og enn fremur að kanna áhuga peirra á tungumálum og tungumálanámi. Ekki hafa áður verið gerðar sambærilegar kannanir við Háskóla Íslands.

\section{Rannsóknin}

Meginmarkmið rannsóknarinnar var að kanna pörf fyrir og áhuga nemenda í grunnnámi við Háskóla Íslands á tungumálanámi. 
Rannsóknin var framkvæmd af Félagsvísindastofnun á tímabilinu 19. febrúar - 4. apríl 2018. Send var út könnun á póstlista nemenda við Háskóla Íslands hi-nem og hún ítrekuð fimm sinnum.

\section{Pátttakendur}

Alls tóku 1210 nemendur eða liðlega 17\% nemenda í grunnnámi við HÍ pátt í könnuninni. Par sem spurt var á íslensku gátu einungis peir sem höfðu gott vald á málinu svarað. Bakgrunnsspurningar leiddu í ljós að alls svöruðu 905 konur eða um 75\% og 305 karlar eða um $25 \%$ svarenda. Aldursdreifing var eins og vænta mátti pví meirihluti svarenda var á aldrinum 22-25 ára eða 51\%. Næstflestir voru á aldrinum 30 ára eða eldri eða $22 \%$ en $17 \%$ voru á aldrinum 26-29 ára og 11\% 18-21 árs. Spurt var um námsár en svarendur voru 1181 og af peim voru 38\% á fyrsta ári, 28\% á öðru ári, 26\% á priðja ári en $8 \%$ á fjórða námsári. Dreifing svarenda var nokkuð jöfn eftir sviðum en tæplega $14 \%(\mathrm{~N}=147)$ nemenda af Menntavísindasviði svöruðu en rúmlega $19 \%(\mathrm{~N}=287)$ nemenda af Hugvísindasviði. Nemendur af öðrum sviðum röðuðu sér parna á milli. Svörin endurspegla pýðið, sem eru allir háskólanemar í grunnnámi eða 7361 nemandi.

\section{Spurningarnar}

Í kjölfar bakgrunnspurninga fylgdu spurningar sem lutu að aðalmarkmiði rannsóknarinnar, sem var að kanna parfir og viðhorf nemenda til tungumálanáms og tungumálafærni. Í peim tilgangi voru settar fram 12 spurningar eftir ákveðnum undirpemum. Undir fyrsta undirpema flokkuðust spurningar um möguleika nemenda til tungumálanáms sem hluta af sínu aðalnámi. Með pessu vildi Málaog menningardeild átta sig á stjórnsýslulegum hindrunum og reglum sem hugsanlega kæmu í veg fyrir að nemendur efldu tungumálakunnáttu meðfram öðru námi.

Pá koma spurningar um reynslu nemenda og áhuga á skiptinámi, tengsl við faglega færni og hvort nemendur teldu að tungumálanám ætti að vera hluti af pví námi sem peir stunduðu. Fyrstu 
spurningunni í pví pema var ætlað að kanna mögulegar parfir peirra fyrir erlend tungumál vegna verkefna sinna hér og nú, en síðari spurningar könnuðu viðhorf nemenda til pess að hve miklu leyti peir teldu að færni í erlendum tungumálum sem kennd eru við Mála- og menningardeild yki faglega hæfni peirra til náms og starfa í framtíðinni. Pá var spurt hvort tungumálanám væri eða ætti að vera val í námi peirra og hversu líklegir svarendur væru til að taka tungumálanámskeið ef svo væri. Einnig var spurt um pekkingu og reynslu af Tungumálamiðstöð Háskóla Íslands (https://www.hi.is/ tungumalamidstod). Аð lokum var spurt hvaða tungumál nemendur vildu helst læra og pá hvers konar færni peir vildu efla s.s. talmál, skilning, fagtengt mál, pekkingu á bókmenntum, menningu o.s.frv.

\section{Greining}

Svör í könnuninni voru greind af sérfræðingum Félagsvísindastofnunar með peirri tölfræði sem er viðeigandi fyrir hverja spurningu. Par sem svarendur tóku ekki allir afstöðu til allra spurninga er mismunandi fjöldi svara á bak við niðurstöður fyrir hverja spurningu. Notuð var einföld lýsandi tölfræði með prósentum fyrir bakgrunnspurningar. Marktektarprófið kí-kvaðrat var notað til að meta hvort tölfræðilega marktækur munur væri á hlutföllum mismunandi hópa eftir bakgrunni. Marktækur munur er tilgreindur á eftirfarandi hátt: *p $\leq 0,05 ; * * \mathrm{p} \leq 0,01 ; * * \mathrm{p} \leq 0,001$. Eftir grunngreiningu, unnu höfundar niðurstöðurnar sem lýst er hér á eftir.

\section{Niðurstöður}

Niðurstöðum bakgrunnspurninga er lýst að framan en í pessum hluta verður gerð grein fyrir öðrum svörum og byrjaðá spurningum um hvort tungumálanám væri hluti af námi svarenda. Yfir $81 \%$ svöruðu að tungumálanám væri ekki hluti af námi sínu og enn fleiri, eða $90 \%$ peirra sem svöruðu pessari spurningu, sögðu að tungumálanám væri ekki hluti af vali í sínu námi. Pá komu prjár spurningar er vörðuðu hugsanlega notkun tungumála í skiptinámi. 
Í töflu 1 má sjá spurningarnar og svörin.

Tafla 1. Hefur pú farið í skiptinám til útlanda í háskólanámi pínu, eða stefnir pú á að fara í skiptinám í framtíðinni?

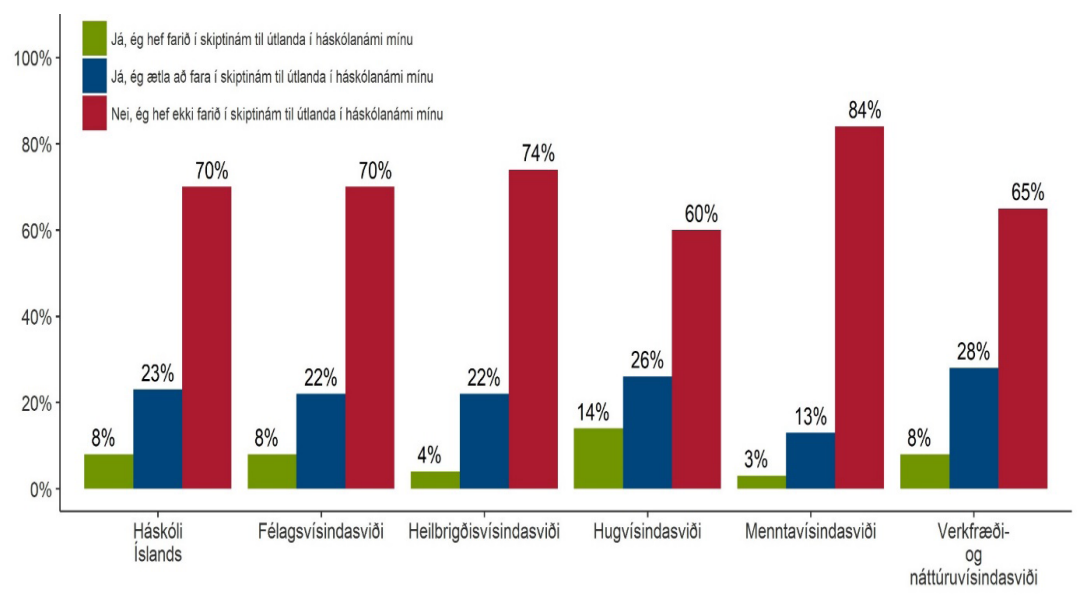

Pegar svör háskólanema eru skoðuð kemur í ljós að aðeins um 8\% svarenda hafa verið í skiptinámi en nærri fjórðungur (23\%) hugðist fara í skiptinám. Svörin eru mismunandi eftir sviðum en flestir svarenda eða $14 \%$ af Hugvísindasviði höfðu farið í skiptinám en aðeins 3\% svarenda af Menntavísindasviði. Menntavísindasvið sker sig einnig úr pegar litið er á fjölda peirra sem ætla sér í skiptinám eða eingöngu 13\% meðan 22-28\% nemenda á öðrum sviðum hugðust fara í slíkt nám.

Pá kom röð spurninga og staðhæfinga sem svarendur voru beðnir að taka afstöðu til. Spurt var um viðhorf til tungumála sem hluta af faglegri hæfni og hvort tungumál ættu að vera hluti af öðru námi. Markmiðið var að átta sig á að hve miklu leyti áhugi nemenda gæfi til kynna að vinna pyrfti að pví að breyta regluverki til að auðvelda peim að gera tungumálanám að formlegum hluta námsleiða eða hvort nemendur væru tilbúnir að taka tungumálanámskeið bó að sú vinna yrði ekki metin til eininga. Tafla 2 sýnir viðhorf svarenda til pess hvort tungumál ættu að vera hluti af námi peirra: 
Tafla 2. Tungumál: Hæfni, val, skylda

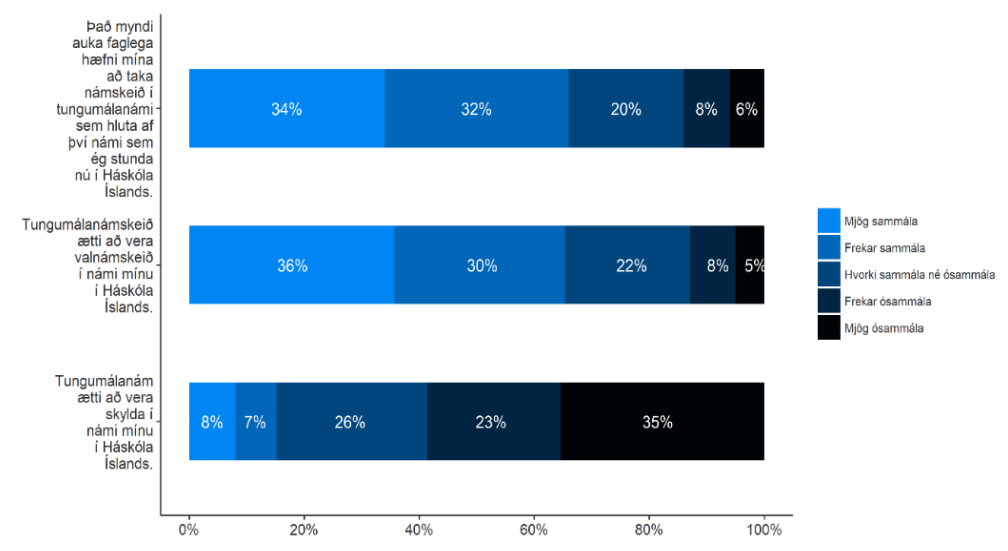

Pannig eru tveir priðju (34\%) nemenda sammála pví að kunnátta í erlendum tungumálum auki faglega hæfni sína og 36\% nemenda telur að námskeið í erlendum tungumálum eigi að vera valnámskeið burtséð frá pví á hvaða sviði pað er. Aðeins 15\% telja hins vegar að tungumálanám eigi að vera skylda í sínu námi.

Tvær spurningar fjölluðu um pað hvort nemendur væru líklegir til að velja tungumálanámskeið, jafnvel pótt einingar fyrir pau væru ekki metnar inn í nám peirra. Um fjórðungur kvaðst líklegur eða frekar líklegur til að bæta slíku námi við pótt pað væri ekki metið til eininga en 22\% sögðust vera líklegir eða frekar líklegir til að taka tungumálanámskeið sem metið væri til eininga.

Tafla 3. Hversu líklegt eða ólíklegt er að pú ...

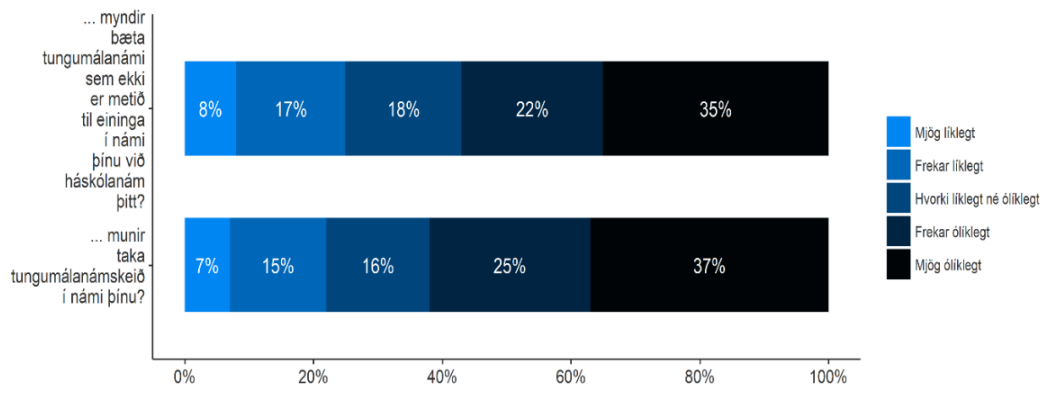


Pátttakendur voru spurðir um færni sína í einstaka tungumáli. Peim var fenginn listi yfir pau tungumál sem kennd eru við Málaog menningardeild og peir beðnir að merkja á skalanum 0-10 par sem 0 var engin færni en 10 var kunnátta á við pá sem hafa málið að móðurmáli. Í peim tilfellum par sem eitt pessara tungumála var móðurmál viðkomandi voru svarendur beðnir að nota töluna 11, og var pá svar peirra ekki tekið með pegar gögnin voru greind.

Eins og búast mátti við kváðust langflestir hafa mjög góða færni í ensku. Af peim 513 sem svöruðu voru 372 sem töldu sig vera á skalanum 7-9 en 96 sögðust hafa færni á við innfædda. Aðeins 41 taldi að enskukunnátta sín væri á bilinu 3-6 og enginn merkti við að hann kynni enga ensku (sjá töflu 4).

Tafla 4. Færni peirra sem merktu við að peir vildu læra viðkomandi tungumál

\begin{tabular}{|l|l|l|l|l|l|}
\hline Tungumál & 5 og undir & 6 og yfir & Tungumál & 5 og undir & 6 og yfir \\
\hline enska & 26 & $1181^{*}$ & ítalska & 234 & 26 \\
\hline danska & 829 & 342 & japanska & 99 & 16 \\
\hline spænska & 616 & 121 & latína & 202 & 16 \\
\hline pýska & 654 & 103 & kínverska & 30 & 19 \\
\hline sænska & 548 & 94 & rússneska & 53 & 10 \\
\hline franska & 423 & 57 & gríska & 39 & 3 \\
\hline
\end{tabular}

* Par af voru 616 sem merktu við 9 og 10 (kunnátta á við innfædda)

Næstu spurningar lutu að pví hvaða tungumál nemendur gætu hugsað sér að skrá sig í. Parna var lítill munur milli sviða en svarendur gátu merkt við fleiri en eitt tungumál. Niðurstöður svara allra pátttakenda má sjá í töflu 5 .

Tafla 5. Tungumál sem svarendur vildu læra.

\begin{tabular}{|l|l|l|l|l|l|l|l|l|l|l|l|l|l|}
\hline & Enska & Dan. & Pýska & Frans. & Jap. & Rúss. & Kín. & Arab. & Sæn. & Spæen. & Grísk & Ítal. & Lat. \\
\hline Alls HÍ & $42 \%$ & $28 \%$ & $36 \%$ & $30 \%$ & $15 \%$ & $11 \%$ & $14 \%$ & $12 \%$ & $26 \%$ & $47 \%$ & $8 \%$ & $24 \%$ & $13 \%$ \\
\hline
\end{tabular}

Marktækur munur er á svörum. Áhugavert er að spænska er pað mál sem flestir vilja læra, síðan enska og svo pýska, franska og 
danska. Gæti petta bent til pess að að nemendur vilji bæta við sig kunnáttu peim málum sem peir hafa pegar lært.

Næstu spurningar voru margpættar en par voru nemendur sem gátu hugsað sér að læra ákveðin tungumál beðnir að merkja við pá pætti tungumálsins sem skipti pá mestu máli. Ef nemandi valdi japönsku, svo dæmi sé tekið, birtist fjölvalsspurning par sem nemandinn var beðinn að raða eftirtöldum páttum eftir mikilvægi:

- almennur lesskilningur

- ritun

- hlustunarskilningur

- talað mál

- fagtengt tungumálanám

- akademísk samskipti

- pvermenningarleg samskipti

- alpjóðleg samskipti

- heimildavinna

- bókmenntir og listir

- menning og saga

- lestur námsefnis

Pessi listi var valinn með tilliti til endurskoðunar kennslumarkmiða og áherslu innan einstakra námsleiða í Mála- og menningardeild. Aðeins svör peirra sem völdu viðkomandi tungumál eru rædd og er pví mismunandi fjöldi nemenda $(\mathrm{N})$ að baki svaranna fyrir hvert tungumál frá 449 í ensku til 106 í grísku. Hér verður gerð stutt samantekt á niðurstöðum en lesendum annars vísað í viðauka 1 hér á eftir en par má finna niðurstöður úr svörum við pessum spurningum með tilliti til einstakra tungumála, 12 tungumála í allt.

Enska hefur algera sérstöðu meðal peirra tungumála sem spurt var um í pessari könnun. Enska er samskiptamál víðast hvar um heiminn og sérstaklega í háskólastarfi. Langflestar eða um 90\% námsbóka við Háskóla Íslands eru ritaðar á ensku og frumtextar sem eiga uppruna utan enskumælandi svæða eru undantekningalítið lesnir í enskum pýðingum. Sífellt fleiri námskeið eru kennd á ensku og lokaritgerðir eru í auknum mæli skrifaðar á ensku í íslenskum háskólum (Birna 
Arnbjörnsdóttir og Hafdís Ingvarsdóttir, 2018). Niðurstöður könnunarinnar styðja niðurstöður fyrri rannsókna sem benda til pess að enskuskilningur háskólanema sé betri en notkunarfærni (Birna Arnbjörnsdóttir og Hafdís Ingvarsdóttir, 2018) pví aðeins fjórðungur peirra 449 sem vildu læra ensku merktu við enskuskilning en ívið fleiri við talmál. Enn fleiri eða 57\% allra vildu leggja stund á fagtengt enskunám og 53\% völdu ensk akademísk samskipti. Flestir eða $71 \%$ völdu pjálfun við lestur námsbóka á ensku. Svörin um enskuna voru talsvert ólík svörum um önnur tungumál, sem endurspeglar sérstöðu enskunnar á Íslandi.

Nemendur sem áhuga hafa á að sækja námskeið í dönsku hafa mestan hug á að bæta talmálsfærni sína eða 89\% almennt en t.d. 94\% á Verkfræði- og náttúruvísindasviði. Tveir priðju nemenda vilja bæði auka skilning sinn á töluðu dönsku máli og ritmáli. Nemendur á Hugvísindasviði hafa mestan áhuga á dönskum bókmenntum, menningu og sögu en áhugi nemenda af öðrum sviðum beinist sî̉ur að peim páttum.

Af peim 272 sem vildu læra sænsku voru 82 af Heilbrigðisvísindasviði, 68 af Verkfræði- og náttúruvísindasviði en færri af öðrum sviðum. Rúmlega helmingur pessara nemenda vilja bæta almenna færni sína í sænsku en einnig bæta lesskilning námsbóka og færni í akademískum samskiptum og skera sig úr hvað pað varðar.

Af peim sem svöruðu voru 383 sem vildu læra pýsku og voru nemendur á Verkfræði- og náttúruvísindasviði mest áberandi en 92\% peirra vildu ná meiri færni í töluðu máli en liðlega helmingur vildi einnig bæta lesskilning á námsefni.

322 svarendur merktu við að peir vildu gjarnan læra frönsku. Af peim vildu $93 \%$ bæta talmálsfærni sína en $96 \%$ nemenda af Hugvísindasviði og Menntavísindasviði vildu bæta talmálsfærni sína í frönsku.

Í töflu 5 kemur fram að flestir svarenda eða $47 \%$ ( $\mathrm{N}=502)$ vildu skrá sig í spænsku. Af peim vildu $93 \%$ bæta sig í töluðu máli en síðan almennt í skilningi og ritun. Minni áhugi virðist vera á öðrum menningarlegum páttum eða sérhæfðri spænsku.

Sama gildir um ítölsku og hin rómönsku málin, spænsku og frönsku, 228 nemendur vildu gjarnan bæta almenna málfærni, sér- 
staklega talmálsfærni í ítölsku bó svo að nemendur á Hugvísindasviði skeri sig úr að pví leyti að tveir priðju peirra vildu kynnast bókmenntum og listum og menningu og sögu Ítalíu.

Af peim 110 nemendum sem gátu hugsað sér að taka námskeið í rússnesku var áberandi áhugi á að bæta almenna málfærni pó svo að tæpur helmingur nemenda á Hugvísindasviði vildi læra um bókmenntir og listir og menningu og sögu og hugsanlega á frummálinu par sem $45 \%$ peirra vildi geta lesið námsbækur á rússnesku.

106 svarendur merktu við að peir gætu hugsað sér að læra grísku, aðallega lestur og talmál. En peir 176 sem vildu læra latínu höfðu mestan áhuga á lestri og ritun.

Námskeið í japönsku eru vel sótt af nemum við Háskóla Íslands. Рað kom pví á óvart að aðeins 155 nemendur kváðust geta hugsað sér að læra japönsku. Flestir svarenda höfou áhuga á að bæta almenna málfærni en af peim svarendum sem völdu bókmenntir, listir, menningu og sögu voru flestir af Menntavísindasviði.

Af peim 150 nemendum sem merktu við kínversku völdu flestir námskeið í almennri málfærni. Tæplega helmingur svarenda af Hugvísindasviði valdi kínverskar bókmenntir og listir og menningu og sögu.

124 nemendur merktu við arabísku sem pað mál sem peir vildu gjarnan læra. Par var mest áberandi valið á námskeiðum í almennri málfærni, p.e. almennum lesskilningi, ritun og hlustunarskilningi en sérstaklega töluðu máli. 65\% nemenda af Verkfræði- og náttúruvísindasviði sem völdu arabísku vildu kynnast bókmenntum og listum og $75 \%$ vildu kynnast menningu og sögu en aðeins færri af Hugvísindasviði höfou áhuga á pessum páttum.

\section{Samantekt}

Prátt fyrir tiltölulega lágt svarhlutfall gefa niðurstöðurnar vísbendingu um viðhorf nemenda Háskóla Ísland til tungumálanáms. Svo virðist sem flestir velji að læra tungumál sem peir hafa áður numið p.e. tungumál sem kennd eru í framhaldsskólum s.s. dönsku, ensku, frönsku og býsku. Í öðru lagi má skipta svarendum í tvo meginhópa eftir vali peirra á tungumálum sem peir geta hugsað sér 
að tileinka sér: Annars vegar virðast nemendur velja tungumál vegna pess að pau hjálpa peim í núverandi eða fyrirhuguðu námi, aðallega tungumálum sem svarendur hafa áđur numið s.s. ensku og dönsku. Par ber mest á vali á talmálspjálfun og lestri námsbóka sem segir hugsanlega eitthvað til um áherslur í tungumálanámi í framhaldsskólum. Hins vegar eru svo nemendur sem vilja bæta við sig tungumálum og hafa pá áhuga á almennri málfærni, bókmenntum, listum og sögu s.s. ítölsku, kínversku, japönsku o.fl.

Hjá fyrri hópnum er enska vinsæl en langflestir vildu bæta lesskilning á námsbókum en fæstir merktu við að peir vildu bæta enskuskilning sinn. Í pessum flokki er einnig að finna dönsku, sænsku og pýsku sem nemendur virðast tengja við framtíðaráform um framhaldsnám. Pannig velja næstum 90\% nemenda talmálspjálfun í dönsku og par af sérstaklega nemendur á Verkfræði- og náttúruvísindasviði. Helmingur allra nemenda vildi líka bæta sig í skilningiánámsbókumádönsku. NemenduráHeilbrigðisvísindasviði eru sérstaklega áhugasamir um sænsku, bæði almenna sænskukunnáttu en líka færni í akademískum samskiptum og lestri námsbóka. Tæplega helmingur peirra sem vildi læra pýsku vildi bæta sig í lestri námsefnis pó svo að flestir vildu bæta almenna málfærni. Petta á einnig við um rómönsku málin, auk kínversku, japönsku, rússnesku og arabísku.

Áhugi nemenda á fagtengdu tungumálanámi kemur fram í pessari könnun, p.e. að nemendur átta sig á pví að færni í erlendu tungumáli eykur hæfni peirra í sínu fagi, hvort sem er í námi eða starfi (sjá töflu 2).

\section{Umræơur}

Til pess að mæta pörfum nemenda Háskóla Íslands sem birtast í niðurstöðum pessarar könnunar, hefur Mála- og menningardeild hafið vinnu við áherslubreytingar í tungumálakennslu m.a. í átt að fagtengdu málanámi í stuttum námsleiðum. Рað er ljóst að nemendum er best pjónað með pví að tungumálanámið sé fellt inn í nám peirra í öðrum greinum annaðhvort með samvinnu um nám- 
skeið pvert á námsgreinar eða með rýmkun reglna um flutning preyttra eininga milli stjórnsýslueininga. Niðurstöður nemendakönnunarinnar sem hér er lýst eru ótvíræðar og kalla beinlínis á slíka pverfaglega próunarvinnu og samstarf.

Eins og fram kom í inngangi pessarar greinar hvetur fjárhagslíkan Háskóla Íslands ekki til samvinnu milli greina, hvað pá pvert á deildir eða svið. Petta hefur áhrif á námsframboð skólans í heild sinni en varðar tungumálakennslu sérstaklega. Heildaráhrif pessa kunna að birtast í tilhneigingu til einsleitni í námskeiðaframboði greina par sem í grunnnámi er einblínt á grunnstoðir námsgreina og í meistaranámi að fjölga námsleiðum, jafnvel langt umfram eftirspurn, frekar en að nýta sérfræðipekkingu akademískra starfsmanna með kjörsviðum innan einstakra greina.

Sem dæmi um hið síðarnefnda má nefna að skólinn býður ekki upp á neina svæðistengda sérhæfingu fyrir meistaranema í sagnfræði, stjórnmálafræði, viðskiptafræði eða bókmenntafræði pó að sérfræðikunnátta til slíks sé til staðar í tungumálunum. Petta pýðir til dæmis að meistaranemi í sagnfræði sem hefur áhuga á SuðurAmeríku parf að óska eftir sérstökum undanpágum til að fella slíka sérhæfingu inn í nám sitt, jafnvel pótt við skólann starfi sérfræðingar í sögu og menningu pessarar heimsálfu.

рað er ekki að undra að tungumálin verði utanveltu pegar deildirnar eiga fjárhagslega ekkert undir pví að auka fjölbreytni og valmöguleika nemenda. Pá er tungumálanám fjarlægur og undarlegur kostur og nemendur purfa að stunda slíkt nám til hliðar við aðalnámsgrein eða fá undanpágur til að bæta slíku við. Tómlæti um tungumálanám gengur jafnvel svo langt í að minnsta kosti einni deild skólans (stjórnmálafræði) að nemendur geta ekki einu sinni fengið einingar fyrir tungumálanámskeið sem hluta af opnu vali (Kennsluskrá Hí).

Færa má margvísleg rök fyrir pví að fjárhagslíkan Háskóla Íslands takmarki akademísk gæði skólans pegar á heildina er litið en hér er vert að beina sjónum sérstaklega að tungumálum og halda pví fram að könnunin sem hér hefur verið gerð grein fyrir gefi tilefni til að ætla að nemendur sjái fagleg tækifæri í tungumálanámi sem yfirstjórn skólans og einstakar deildir hafa ekki komið auga á. Niðurstöður sýna að áhugi peirra sem tóku pátt í könnuninni á 
tungumálanámi til að styrkja stöðu sína menningarlega, félagslega og akademískt er mun meiri en aðsókn að tungumálanámskeiðum ein og sér gefur til kynna.

Um petta má segja tvennt: Í fyrsta lagi er ekki útilokað að nemendur séu framsýnni en stjórnendur deilda um hvaða færni sé gagnleg og mikilvæg pegar til lengri tíma er litið og í öðru lagi er pessi niðurstaða í samræmi við nokkurra áratuga faglega umræðu um erlend tungumál sem hluta af háskólanámi. Margir bandarískir háskólar hafa frá pví á níunda áratugnum boðið upp á „tungumál pvert á greinar" (e. Foreign Languages Across the Curriculum, FLAC) - valkost sem gerir nemendum kleift að tengja tungumálanám við einstakar námsgreinar innan sinna námsleiða (Caldwell, 2001, bls. 1127). Cornell-háskóli í Bandaríkjunum hefur verið að próa slíka valkosti undanfarin fjögur ár með góðum árangri og Colgateháskóli í Bandaríkjunum hefur margra ára reynslu af pví að auðvelda tungumálanám með pessum hætti (sjá Tungumálamiðstöð Cornell-háskóla og Tungumál pvert á greinar hjá Colgate-háskóla).

Markmiðin með tungumálanámi af pessu tagi eru nokkur. Við Colgate-háskóla er námið sniðið að prennskonar pörfum: Í fyrsta lagi pörf fyrir grunnpekkingu á tungumáli sem eykur skilning nemenda á menningarlegum fjölbreytileika og getur líka aukið rannsóknagetu framhaldsnema töluvert vegna aukins aðgangs að gögnum á erlendum tungumálum. Í öðru lagi pörf fyrir að viðhalda og bæta við kunnáttu í tungumáli sem nemendur kunna fyrir og í priðja lagi markvissari pjálfun í tungumáli til að geta sinnt ákveðnum störfum, samskiptum eða pjónustu. En markmiðin geta verið margvísleg eftir stærð og gerð einstakra námsleiða. Í pessu sambandi er mikilvægt að huga að pörfum samfélagsins, nemenda og peirrar sérpekkingar sem skólar búa yfir, svo dæmi sé tekið (Sudermann \& Cisar, 1992, bls. 296-297).

Um langt skeið hefur almennt verið viðurkennt að pekking og skilningur á menningarlegum margbreytileika og sérkennum menningarsvæða getur verið lykilatriði í faglegum og fagtengdum samskiptum. Engum dettur til dæmis í hug lengur að vænlegt sé að hasla sér völl í Austur-Asíu eða á Indlandi án pess að hafa skilning á menningu pessara svæða - sama hvort um er að ræða viðskipti, opinber samskipti, samskipti við kollega eða annað. En án pekk- 
ingar á tungumálum einstakra svæða er menningarskilningurinn alltaf takmarkaður. Pess vegna hefur líka á síðustu árum færst í aukana að fjöl- og pvermenningarleg kennsla feli einnig í sér tungumálakennslu eins og dæmin frá Colgate og Cornell sýna prýðilega.

Раð sem meira er: Með síauknum menningarlegum fjölbreytileika innan samfélaga sem áđur voru einsleitari er pörfin fyrir tungumálakunnáttu ekki einungis tengd fjarlægum slóðum heldur einnig og ekki síður við störf heima fyrir. Í pessu sambandi hefur verið rætt um hnattræna alpjóðlega og fjölmenningarlega færni (e. Global International and Intercultural Competencies, GII) sem er hluti af alpjóðavæðingu náms hvort sem fyrirhugaður starfsvettvangur er heima eða heiman. Pannig hefur kennslulíkan sem kennt er við Menningu og tungumál pvert á greinar (e. Cultures and Languages Across the Curriculum, CLAC) t.d. rutt sér til rúms í námi á sviði opinberrar stjórnsýslu. Рað felur í sér að pjálfun í menningu og tungumálum er talin lykilpáttur í menntun á pessu sviði og námsleiðin endurskipulögð í samræmi við pað (Capobianco o.fl., 2018).

Full ástæða er til að mæla með pví að Háskóli Íslands taki stefnu sína um kennslu í erlendum tungumálum til rækilegrar endurskoðunar. Í núgildandi stefnu Háskóla Íslands er aukin pátttaka nemenda í alpjóðastarfi meðal markmiða skólans og aðgerðir meðal annars fólgnar í pví að „[e]instakar deildir meti hvort auðvelda megi nemendum að stunda tungumálanám sem hluta af námi til að auka faglega hæfni“" (Stefna Háskóla Íslands 2016-2021). Að okkar mati parf að próa pennan pátt betur og skerpa á honum. Í fyrsta lagi verður að hafa í huga að á sî̉ustu árum hefur alpjóðavæðing verið hluti af samfélagspróun um allan heim, par á meðal á Íslandi. Um eða yfir fimmtungur landsmanna er að minnsta kosti að hluta af erlendum uppruna og hefur alist upp við fleiri tungumál en íslensku. Pess vegna er tungumálakunnátta ekki aðeins nauðsynleg í samskiptum utan Íslands heldur líka á heimavelli. Í öðru lagi parf að gefa miklu meiri gaum að faglegum styrk tungumálakunnáttu. Alltof algengt er að litið sé svo á í deildum að enskukunnáttan ein skipti máli pegar um rannsóknarstarf eða fagleg samskipti er að ræða. Eins og könnunin sýnir virðast sumir nemendur vera á öðru máli. Niðurstöður rannsókna Birnu Arnbjörnsdóttur og Hafdísar Ingvarsdóttur (2018) staðfesta petta. Í priðja lagi er Háskóli Íslands 
nægilega stór stofnun til að geta staðið undir mun meiri fjölbreytileika en raunin er nú. En til pess að skólinn geti nýtt kunnáttu peirra sérfræðinga sem innan hans starfa parf að breyta rekstrarlíkani skólans - og kannski um leið hugsunarhætti - pví rekstrarlegar forsendur hafa pví miður sterk áhrif á hugsun um og skilning á faglegum páttum. 


\section{Viðhorf háskólastúdenta til tungumálakunnáttu}

Nemendur við Háskóla Íslands telja að faglegur ávinningur felist í tungumálanámi. Stór hluti peirra myndi bæta við sig tungumálakunnáttu ef slíkt félli betur að námi í einstökum greinum en raunin er oftast nú. Petta er niðurstaða könnunar sem Félagsvísindastofnun gerði fyrir Mála- og menningardeild og fjallað er um í pessari grein. Bent er á að flestar deildir Háskóla Íslands skipuleggi nám í einstökum greinum pannig að erfitt eða ókleift er að fella tungumálanám að pví, jafnvel pótt nemendur hafi áhuga á slíkri viðbót og auðvelt sé að sýna fram á faglegan ávinning. Í greininni er sýnt fram á að fjárhagsmódel skólans vinnur beinlínis gegn pví að nemendur geti aukið sérpekkingu sína á einstökum svæðum, menningarheimum og tungumálum. Niðurstaða höfunda er sú að petta dragi úr gæðum námsins almennt og kalla purfi eftir kerfisbreytingum sem auðvelda nemendum að fella tungumálakunnáttu inn í fagbekkingu sína.

Lykilorð: tungumálakunnátta, gæði náms, faglegur ávinningur, kerfisbreyting 


\section{Students and Language Learning: \\ A Survey}

Students at the University of Iceland report that the study of languages brings professional benefit. Many of them would like to increase their foreign language skills if that could be better built into their programs This is the result of a survey made by the Social Science Research Institute for the Faculty of Languages and Cultures. This paper points out that most faculties at the University of Iceland make it difficult or impossible to study a foreign language as a part of a degree program, even when the students are interested in such a combination and the benefit can easily be shown. The authors of this paper show that the funding structure of the University of Iceland directly prevents students from increasing and deepening their knowledge of regions, cultures and languages. The authors conclude that these limitations reduce the quality of the study programs at the University and that system change is necessary to enable students to build language skills into their professional training and academic study.

Keywords: foreign language skills, academic quality, professional benefit, system change 


\section{HEIMILDIR}

Birna Arnbjörnsdóttir og Hafdís Ingvarsdóttir. (2018). Language development across the lifespan: The impact of English on education and work in Iceland. Amsterdam: Springer.

Capobianco, S., Chen, X., Líppez-De Castro, S., og Rubaii, N. (2018). Enhancing global and intercultural competencies in Master of Public Administration classes: Assessing alternative approaches to incorporating cultures and languages. Teaching Public Administration, 36(2), 178-200.

Caldwell, A. (2001). A FLAC model for increasing enrollment in foreign language classes. The French Review, 74(6), 1125-1137.

Europass. https://europass.cedefop.europa.eu/sites/default/files/cefr-is.pdf

Goethe, J.W. (1949). Goethes poetische Werke: Goethes Schriften, 2, 91. Stuttgart: Cotta.

Hæfniviðmið. https://vefir.mms.is/namsmat/pdf/haefnividmid/erlend/erlend.pdf.

Kennsluskrá HÍ. https://ugla.hi.is/kennsluskra/index.php?tab=nam\&chapter=nams leid\&id=100900_20196\&kennsluar=2019.

Sudermann, D., og Cisar, M. (1992). Foreign Language Across the Curriculum: A Critical Appraisal. The Modern Language Journal, 76(3), 295-308.

Tungumálamiðstöð. https://www.hi.is/tungumalamidstod.

Tungumálamiðstöð Cornell-háskóla. http://lrc.cornell.edu/languages-across-curriculum

Tungumál pvert á greinar. https://www.colgate.edu/about/campus-services-andresources/foreign-languages-across-curriculum-program.

Stefna Háskóla Íslands. https://www.hi.is/sites/default/files/atli/pdf/kynningar/baeklingar/stefna_hi_2016-2021.pdf. 
VIĐAUKI I

\section{Tungumálanámskeið}

Q1 Á hvaða misseri ert pú í núverandi grunnnámi pínu í Háskóla Íslands?
1. misseri
2. misseri
3. misseri
4. misseri
5. misseri
6. misseri
7. misseri
8. misseri
Veit ekki
Vil ekki svara

Qa Ert pú íslenskur ríkisborgari?

Já

$\mathrm{Nei}$

Vil ekki svara

Qb Ríkisborgari hvaða lands ert pú?

Qc modurmal Er íslenska móðurmál pitt?

Já

$\mathrm{Nei}$

Vil ekki svara 
Qd modurmal_b Hvert er móðurmál pitt?

Q2 Hefur pú farið í skiptinám til útlanda í háskólanámi pínu, eða stefnir pú á að fara í skiptinám í framtíðinni?

Já, ég hef farið í skiptinám til útlanda í háskólanámi mínu Já, ég ætla að fara í skiptinám til útlanda í háskólanámi mínu

Nei, ég hef ekki farið í skiptinám til útlanda í háskólanámi mínu

Veit ekki

Vil ekki svara

Q3 Hversu mikla kunnáttu hefur pú í eftirtöldum tungumálum. Notaðu kvarðann 0-10, par sem 0 stendur fyrir enga kunnáttu og 10 fyrir að tala og skrifa fullkomlega?

$\begin{aligned} & \text { Engin } \\ & \text { kunn- } \\ & \text { átta } 0\end{aligned}$
1

Tala og skrifa fullkomlega 10

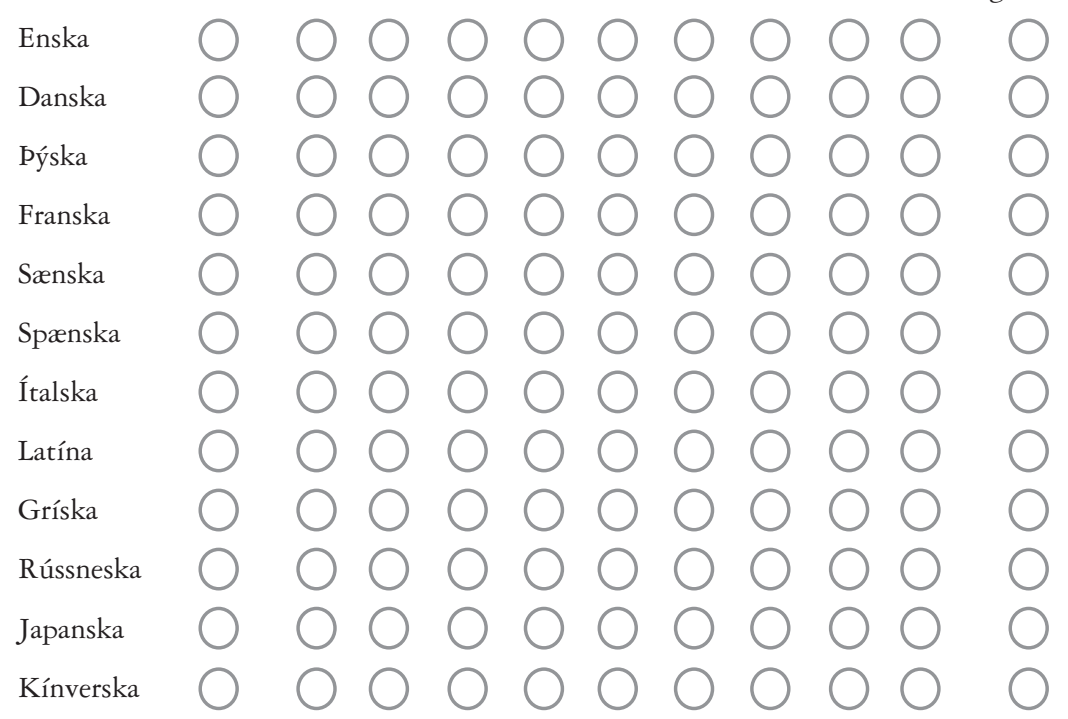


Q4 Er tungumálanám hluti af núverandi námi pínu við Háskóla Íslands?

Já, pað er skylda í námi mínu

Já, ég tek pað sem valnámskeið í námi mínu

Já, ég er í tungumálanámi sem aukagrein í námi mínu

$\mathrm{Nei}$

Veit ekki

Vil ekki svara

Q5 Vilt pú geta tekið tungumálanámskeið í vali sem hluta af námi bínu?

Já, vil læra nýtt tungumál

Já, vil bæta við kunnáttu mína í erlendu máli

Nei

Veit ekki

Vil ekki svara

Q6 Hversu sammála eða ósammála ertu eftirfarandi fullyrðingum?

$\begin{array}{cccccccc}\text { Mjög } & \text { Frekar } & \text { Hvorki } & \text { Frekar } & \text { Mjög } & \text { Veit } & \text { Vil } \\ \text { sam- } & \text { sam } & \text { sam- } & \text { ósam } & \text { ósam- } & \text { ekki } & \text { ekki } \\ \text { mála } & \text { mála } & \text { mála né } & \text { mála } & \text { mála } & & \text { svara } \\ \text { mála } & & & & & & \end{array}$

Pað myndi auka faglega hæfni mína að taka námskeið í tungumálanámi sem hluta af pví námi sem ég stunda nú.

Tungumálanám skeið ætti að vera valnámskeið í námi mínu.
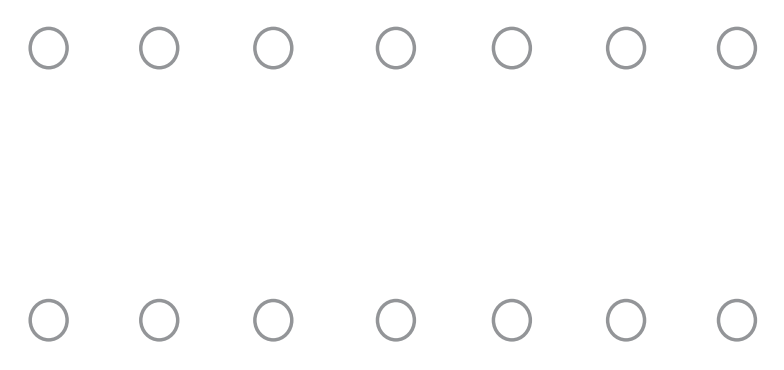
Q7 Er boðið upp á tungumálanámskeið sem valnámskeið í pví námi sem pú stundar nú hjá Háskóla Íslands?
Já
$\mathrm{Nei}$
Veit ekki
Vil ekki svara

Q8 Vilt pú geta tekið tungumálanámskeið í vali sem hluta af námi bínu?
Já
$\mathrm{Nei}$
Veit ekki
Vil ekki svara

Q9 Hversu líklegt eða ólíklegt er að pú munir taka tungumálanámskeið í pví námi sem pú stundar nú?

Mjög líklegt

Frekar líklegt

Hvorki líklegt né ólíklegt

Frekar ólíklegt

Mjög ólíklegt

Veit ekki

Vil ekki svara

Q10 Hvað af eftirtöldu á best við um pekkingu og reynslu pína af Tungumálamiðstöðinni?

Hef aldrei heyrt um Tungumálamiðstöðina

Hef heyrt um hana en pekki ekki til Tungumálamiðstöðvarinnar að neinu leyti

Hef heyrt um Tungumálamiðstöðina og pekki lítillega til hennar

Pekki vel til Tungumálamiðstöðvarinnar en hef ekki tekið 
námskeið par

Hef tekið námskeið hjá Tungumálamiðstöðinni

Q11 Hér fyrir neðan eru pau tungumál sem kennd eru við Háskóla Íslands. Vinsamlegast merktu við pau námskeið sem pú gætir hugsað pér að skrá pig í.
Enska
Danska
Pýska
Franska
Sænska
Spænska
Ítalska
Latína
Gríska
Rússneska
Japanska
Kínverska

Q12 Eru einhver önnur tungumál en fyrrgreind tungumál, sem pú gætir hugsað pér að skrá pig í, ef pau væru kennd?

Já, hvaða?

Nei

Veit ekki

Vil ekki svara

Athugið að hér vantar spurningar um hvers konar færni nemendur vildu tileinka sér í erlendum tungumálum. 